PUBLIK: Jurnal Manajemen Sumber Daya Manusia, Administrasi dan Pelayanan Publik Sekolah Tinggi Ilmu Administrasi Bina Taruna Gorontalo

Volume V Nomor 2 Desember 2018

\title{
PERAN KEPALA DESA DALAM PENYELESAIAN KONFLIK DI OBYEK WISATA PANTAI BOTUTONUO KECAMATAN KABILA BONE KABUPATEN BONE BOLANGO
}

\author{
Daud Maku \& Agus Pariono \\ STIA Bina Taruna Gorontalo \\ bukujurnalstia@binataruna.ac.id ${ }^{1}$ \& guspri811@gmail.com ${ }^{2}$
}

\begin{abstract}
ABSTRAK
Tujuan penelitian ini adalah untuk memperoleh gambaran yang jelas tentang Peran Kepala Desa Dalam Penyelesaian Konflik Obyek wisata Pantai Botutonuo Kecamatan Kabila Bone Kabupaten Bone Bolango dengan mengunakan fokus Komunikasi, Fasilitator, Inovator dan Pengawasan. Jenis penelitian yang digunakan adalah jenis deskriptif pendekatan kualitatif

Hasil penelitian menunjukkan ditinjau dari sisi komunikasi bahwa kepala desa di dalam menyelesaiakan konflik belum maksimal, hal ini disebabkan kepala desa jarang menghadiri musyawarah atau rapat, sehingga upaya penyelesaian konflik tidak berjalan baik dan tidak membuahkan hasil yang sesuai harapan; ditinjau dari sisi fasilitator, kurangnya peran kepala desa sebagai fasilitator dalam memediasi penyelesaian konflik. Oleh sebab itu konflik terus berlangsung; ditinjau dari sisi inovator bahwa kepala desa minim ide-ide atau gagasan yang kreatif di dalam menyelesaiakan konflik; ditinjau dari sisi pengawasan bahwa kepala desa belum maksimal dalam mengawasi benih-benih konflik karena tidak langsung tetapi hanya mengandalkan petugas keamanan desa, sehingga membuat konflik tidak terselesaikan dengan baik sesuai yang diharapkan.

Disarankan bahwa perlunya kerja sama antara kepala desa dan aparat desa didalam menyelesaiakan konflik dan komunikasi yang baik antara kepala desa dan masyarakat sekalipun di dalam pengelolaan hasil dari obyek wisata kepala desa tidak dilibatkan, agar supaya terjalin hubungan yang baik antara kepala desa dan masyarakat. kepala desa seharusnya berusaha meluangkan waktunya untuk masyarakat terutama di dalam menghadiri setiap pertemuan atau musyawarah, sehingga kepala desa dapat mengetahui permasalahan yang ada di masyarakatnya. Penyelesaian konflik dan pengelolaan obyek wisata perlu melibatkan pemerintah dalam hal ini yaitu kepala desa.
\end{abstract}

\section{Kata Kunci: Peran, Kepala Desa, Konflik}

\section{PENDAHULUAN}

Wisata merupakan sektor yang kuat terhadap perubahan dan sektor yang sangat menjanjikan. Wisata sebagai salah satu sektor yang memiliki kontribusi penting terhadap penciptaan lapangan kerja, pertumbuhan ekonomi, dan penghidupan yang layak serta mendorong pemerintah daerah untuk membangun dan memelihara infrastruktur sehingga kualitas hidup 
masyarakat setempat juga meningkat. Indonesia kaya akan berbagai potensi alam yang belum tergali di berbagai daerah yang dapat dijadikan objek dan daya tarik wisata.

Melimpahnya kekayaan alam Indonesia berupa keadaan alam flora dan fauna yang sangat banyak memberikan daya tarik tersendiri bagi para wisatawan domestik maupun wisatawan mancanegara dan apabila hal tersebut dikembangkan dapat menjadi modal bagi pengembangan dan peningkatan sektor pariwisata di daerah setempat khususnya. Modal potensi alam yang melimpah tersebut perlu dimanfaatkan secara optimal melalui penyelenggaraan kepariwisataan yang ditujukan untuk meningkatkan pendapatan daerah, dan memiliki berbagai keuntungan misalnya dalam rangka untuk meningkatkan kesejahteraan masyarakat setempat, memperluas kesempatan kerja, mendorong pembangunan daerah, memperkenalkan dan mendayagunakan potensi alam tersebut. Beragamnya potensi alam yang dimiliki Indonesia sangat menjual bagi dunia kepariwisataan.

Provinsi Gorontalo merupakan salah satu provinsi di Indonesia yang memiliki beragam tempat wisata yang menarik dan banyak dikunjungi oleh wisatawan. Provinsi ini memiliki banyak potensi wisata seperti: panorama dan keindahan alam di daerah tujuan wisata yang tersebar di berbagai daerah kabupaten. Dilihat dari obyek dan daya tarik, wisata alam memiliki potensi yang sangat bagus untuk dikembangkan dan dapat berperan penting dalam meningkatkan pariwisata di Gorontalo.

Salah satu daerah wisata adalah Botutonuo yang terletak di Kecamatan Kabila Bone Kabupaten Bone Bolango yang terkenal dengan wisata pantainya dan memiliki berbagai ragam sumber daya alam, sebagai objek dan daya tarik wisata. Sumber daya alam tersebut merupakan salah satu aset potensial kepariwisataan nasional.

Objek wisata ini memunculkan sebuah tantangan pada generasi sekarang. Agar kiranya mampu mengembangkan dan mengelola potensi wisata tersebut, sehingganya tempat wisata tersebut dapat dijadikan sebagai sarana pendapatan bagi masyarakat setempat, khususnya.

Wisata pantai di Desa Botutonuo adalah wisata yang hanya dikelola oleh masyarakat tanpa ada campur tangan dari pihak pemerintah, baik pemerintah pusat maupun pemerintah daerah, dan hal demikian dapat membuat masyarakat memiliki peluang besar untuk mengelola wisata pantai tersebut dan menciptakan lapangan kerja, dalam rangka meningkatkan ekonomi masyarakat, akan tetapi, kurangnya kemampuan manajemen yang dimiliki oleh masyarakat membuat masyarakat susah untuk mengelola potensi wisata pantai tersebut, dan kadang kalah sering terjadi konflik antar warga yang ingin membuat tempat usaha di dekat wisata pantai tersebut, dikarenakan penataan tempat usaha belum tertata dengan baik. Maka dari itu, untuk menyelesaiakan konflik tersebut, dibutuhkanlah komunikasi yang baik 
antar kepala desa dan masyarakat agar terjalin hubungan yang baik, sehingga pengelolaan obyek wisata pantai dapat terlaksanakan dengan baik. kemudian dibutuhkan juga peran serta tuntutan kepemimpinan dari seorang kepala desa sebagai fasilitator untuk menyelesaikan konflik serta membantu masyarakatnya dalam mengembangkan dan melaksanakan pengelolaan potensi obyek wisata pantai, selain itu, kepala desa juga berperan sebagai inovator yang memberikan ide-ide atau gagasan yang kreatif untuk memimpin masyarakat ke arah yang lebih baik karena seorang pemimpin memiliki tugas dan kewajiban untuk meningkatkan pembangunan desa dan mensejaterahkan kehidupan warganya, dan kepala desa juga memiliki kewajiban melakukan pengawasan terhadap masyarakatnya yang mengelola potensi wisata, agar tidak terjadi konflik antara masyarakat, walaupun kepala desa tidak dilibatkan dalam pengelolaan wisata tersebut.

Namun, berdasarkan pengamatan Obyek Wisata Pantai di Desa Botutonuo Kecamatan Kabila Bone Kabupaten Bone Bolengo peran kepala desa belum optimal, disebabkan kurangnya komunikasi antara kepala desa dan masyarakat sehingga membuat pengelolaan obyek wisata pantai tidak berjalan dengan baik. Kemudian kurangnya peran kepala desa sebagai fasilitator dalam memediasi menyelesaikan konflik yang terjadi antar masyarakat, sehingga sampai saat ini konflik antara warga masih sering terjadi. Dan kemudian, kurangnya peran kepala desa sebagai inovator yang memberikan ide-ide dan gagasan yang kreatif kepada masyarakat, sehingga membuat pengelolaan obyek wisata pantai tidak maksimal. Permasalahan lainnya, kurangnya pengawasan dari kepala desa terhadap masyarakatnya yang mengelola obyek wisata, sehingga masih sering terjadi konflik antara masyarakat yang mengelola obyek wisata tersebut.

\section{PERMASALAHAN}

Berdasarkan uraian latar belakang dan identifikasi masalah di atas, maka rumusan masalah dalam penelitian ini adalah: bagaimanakah peran kepala desa dalam penyelesaian obyek wisata pantai di Desa Botutonuo Kecamatan Kabila Bone Kabupaten Bone Bolango?

\section{TUJUAN DAN MANFAAT PENELITIAN}

\section{Tujuan Penelitian}

Penelitian ini bertujuan untuk memperoleh gambaran tentang bagaimana perang kepalah desa dalam penyelesaian konflik wisata pantai di Desa Botutonuo Kecamatan Kabila Bone Kabupaten Bone Bolango.

\section{Manfaat Penelitian}

Manfaat yang diharapkan atau diinginkan dalam penelitian ini adalah sebagai berikut:

Manfaat teoritis adalah sebagai kajian dalam pengembangan ilmu administrasi, khususnya mengenau peran kepala desa 
dan sebagai pembanding dalam penelitian selanjutnya.

Manfaat praktis penelitian ini sebagai bahan masukan bagi pihak pemerintah desa dapat dijadikan sebagai imformasi yang berharga dalam rangka memajukan sektor wisata.

\section{METODE PENELITIAN}

Penelitian ini menggunakan jenis penelitian deskriptif dengan pendekatan kualitatif. Penelitian deskriptif oleh Mochtar (2008:76) dalam bukunya Metodologi Penelitian Kualitatif adalah menggambarkan berbagai fenomena informasi yang berkaitan dengan fokus penelitian secara menyeluruh secara faktual dan akurat sebagaiman adanya. Sedangkan pendekatan kualitatif menurut Williams (dalam Usman, dan Akbar, 2008:78) dalam bukunya Motode Penelitian Kualitatif, mengemukakan bahwa pendekatan kualitatif adalah pengumpulan data yang disugukan dalam bentuk informasi pada latar alamiah, dengan menggunakan metode alamiah, dan dilakukan oleh orang atau peneliti yang tertarik secara alamiah.

Sumber data penelitian ini berasal dari data primer dan sekunder. Teknik pengumpulan data diperoleh melalui observasi, wawancara dan dokumentasi. Sedangkan analisis data dilakukan melalui reduksi, penyajian dan verifikasi data.

\section{Fokus Penelitian}

Penelitian ini difokuskan pada peran kepala desa dalam penyelesaian obyek wisata pantai di Desa Botutonuo Kecamatan Kabila Bone Kabupaten Bone Bolango, yang dilakukan melalui 4 (empat) aspek, yaitu:

\section{Komunikasi}

Yang dimaksud komunikasi dalam penelitian ini adalah komunikasi yang baik antara kepala desa dan masyarakat dalam hal penyelesaian konflik.

\section{Fasilitator}

Yang dimaksud fasilitator dalam penelitian ini adalah tugas atau wewenang kepala desa dalam memberikan bantuan dan menjadi narasumber yang baik serta mempertemukan pihak yang bertikai untuk berbagai permaslahan.

\section{Motivator}

Yang dimaksud motivator dalam penelitinian ini adalah tugas atau wewenang kepala desa dalam memberikan dorongan atau semangat kepada masyarakat, agar kiranya masyarakat tersebut tidak patah semangat didalam mencapai tujuannya.

\section{Pengawasan}

Yang dimaksud pengawasan dalam penelitian ini adalah sebuah kegiatan yang harus dilakukan oleh kepala desa terhadap masyarakat yang bertujuan untuk mengetahui atau melihat keadaan keadaan masyarakatnya, terkhusus masyarakat yang mengelola obyek wisata. 


\section{HASIL PENELITIAN DAN PEMBAHASAN}

Berdasarkan hasil penelitian melalui analisis dan wawancara dengan para informan serta indikator-indikator yang telah ditetapkan, maka dapat diketahui bahwa peran kepala desa dalam penyelesaian obyek wisata pantai di Desa Botutonuo Kecamatan Kabila Bone Kabupaten Bone Bolango, dapat dijelaskan melalui aspek-aspek sebagai berikut:

\section{Komunikasi}

Salah satu peran kepala desa dalam menyelesaikan konflik adalah melakukan komunikasi yang baik dengan masyarakat agar tejalin hubungan yang baik dengan masyarakat, terutama masyarakat yang berkonflik, yang ada di dekat obyek wisata Botutonuo, sehingga pengelolaan obyek wisata pantai Botutonuo dapat terlaksana dengan baik.

Hasil penelitian menunjukkan bahwa peran kepala desa didalam menyelesaikan konflik yang ada di obyek wisata pantai botutonuo, belum dilaksanakan dengan maksimal, sisebabkan kurangnya komunikasi antara kepala desa dan masyarakat, dan kepala desa hanya melibatkan aparat desa didalam menyelesaikan konflik tersebut. Sehingga konflik yang ada di obyek wisata pantai botutonuo belum dapat diselesaikan.

\section{Fasilitator}

Fasilitator adalah suatu peran dari kepala desa didalam menyelesaikan konflik yang ada di Obyek Wisata Pantai Botutonuo, dimana seorang kepala desa dituntut untuk menjadi fasilitator yang baik bagi masyarakatnya terutama didalam mengembangkan dan melaksakan pengelolaan potensi Obyek Wisata Pantai di Desa Botutonuo, agar pengelolaan potensi obyek wisata pantai tersebut berjalan dengan baik.

Hasil penelitian menunjukkan bahwa dibutuhkannya peran kepala desa sebagai fasilitator dalam hal memimpin masyarakat untuk menyelesaikan konflik yang ada di obyek wisata pantai botutonuo belum dilaksanakan dengan baik, disebabkan kepala desa sebagai fasilitator jarang hadir di musyawarah atau rapat yang diadakan oleh aparat desa, sehingga konflik yang ada di obyek wisata botutonuo tidak dapat di selesaikan dengan baik.

\section{Motivator}

Inovator merupakan peran dari kepala desa di dalam pengelolaan obyek wisata pantai, dimana seorang kepala desa dituntut untuk memberikan ide-ide atau gagasan yang kreatif untuk memimpin masyarakatnya kearah yang lebih baik. Karena seorang pemimpin memiliki tugas dan kewajiban untuk meningkatkan pembangunan desa dan mensejaterahkan kehidupan warganya. Hasil penelitian menunjukkan bahwa peran kepala desa sebagai inovator dalam hal penyelesaian konflik dan pengembagan potensi obyek wisata pantai di Desa Botutonuo belum terlaksana dengan baik, disebabkan kepala desa kurang melibatkan diri dalam menyelesaikan konflik dan jarang mendatangi obyek wisata pantai di Desa 
Botutonuo. Sehingganya potensi obyek wisata tidak berkembang dengan baik.

\section{Pengawasan}

Pengawasan merupakan salah satu tugas dari kepala desa di dalam menjaga keamanan masyarakatnya dan juga terhadap pengelolaan obyek wisata pantai Botutonuo, supaya tidak terjadi konflik antara masyarakat dan pengeloaan obyek wisata pun dapat berjalan dengan baik. Sekalipun kepala desa tidak dilibatkan dalam pengelolaan obyek wisata tersebut.

Hasil penelitian menunjukkan bahwa pengawasan yang dilakukan oleh kepala desa di Obyek Wisata Pantai di Desa Botutonuo belum maksimal, disebabkan kepala desa jarang mendatangi obyek wisata dan hanya mengandalakan petugas keamanan desa. Sehingga membuat penyelesaian konflik di obyek wisata tidak berjalan dengan baik dan tidak sesuai dengan yang diharapkan.

\section{SIMPULAN}

Berdasarkan hasi pembahasan, maka dapat disimpulkan sebagai berikut:

1. Bahwa kepala desa di dalam menyelesaiakan konflik belum maksimal, disebabkan oleh kepala desa yang jarang menghadiri musyawarah atau rapat yang dibuat oleh aparat desa lainynya. Sehingga upaya penyelesaian konflik tersebut tidak berjalan baik dan tidak membuahkan hasil yang sesuai harapan.
2. Bahwa kepala desa sebagai fasilitator dalam hal memediasi penyelesaian konflik. Membuat konflik tersebut sulit untuk diselesaikan. Sehingganya menjalankan tugasnya sebagai fasilitator dengan baik, terutama didalam menyelesaiakan konflik. Agar supaya konflik di Obyek Wisata tersebut bisa terselesaikan dengan baik sesuai yang diharapkan.

3. Bahwa kepala desa dituntut untuk memberikan ide-ide atau gagasan yang kreatif didalam menyelesaiakan konflik atau mengembangkan potensi dari Obyek Wisata. namun hal ini tidak dilaksanakan oleh kepala desa dengan baik. Sehingga penyelesaian konflik pun tidak membuahkan hasil yang baik begitu juga dengan pengelolaan potensi wisata tidak berkembang dengan baik.

4. Bahwa kepala dalam pengawasan dalam hal ini melibatkan seluruh aparat desa terutama kepalah desanya, akan tetapi dalam hal pengawasan ini terlihat belum maksimal, sebab kepala desa tidak turun langsung untuk menyelesaiakan konflik. Kepala desa hanya mengandalkan petugas keamanan desa, sehingga membuat konflik tidak terselesaikan dengan baik sesuai yang diharapkan.

\section{SARAN}

Berdasarkan simpulan tersebut maka dapat disarankan sebagai berikut:

1. Perlunya kerja sama antara kepala desa dan aparat desa di dalam menyelesaiakan konflik dan 
komunikasi yang baik antara kepala desa dan masyarakat sekalipun di dalam pengelolaan hasil dar obyek wisata kepala desa tidak dilibatkan, agar supaya terjalin hubungan yang baik antara Kepala Desa dan masyarakat.

2. Perlunya kepala desa meluangkan waktunya untuk masyarakat sebagai fasilitator terutama di dalam menghadiri setiap pertemuan atau musyawarah, sehingga kepala desa dapat mengetahui permasalahan yang ada dimasyarakatnya.

3. Perlunya kepala desa menjadi motivator dalam mengelola obyek wisata agar fasilitas yang dikelola oleh masyarakat semakin ditingkatkan.

4. Perlunya kepala desa ikut melakukan pengawasan dalam pengelolaan obyek wisata agar tidak terjadi konflik di antara anggota masyarakat yang mengelola obyek tersebut.

\section{DAFTAR PUSTAKA}

A.A. Anwar Mangkunegara. 2009. Manajemen Sumber Daya Manusia. Bandung: PT. Remaja Rosdakarya.

A. Shitong. 2007. Manajemen Sumber Daya Manusia. Jakarta: Pradya Paramita.

A, Fauzi. 2007. Manajemen Sumber Daya Manusia. Jakarta: PT. Elex Media Komputindo.

Arifin. 2012. Pemimpin dan Kepemimpinan. Jakarta: Raja Grafindo Press.
Ahmad Tanzeh, Pengantar Metode Penelitian. Yogyakarta: Teras. 2009.

Anatan, Lina dan Ellitan, Lena. 2009. Manajemen Sumber Daya Manusia Dalam Bisnis Modern. Bandung: Alfabeta.

A Noe Raymond, R Hollenbeck, Gerhart Barry, M Wright Patrick, Hasibuan. 2010. Manajemen Sumber Daya Manusia. Jakarta: Salemba Empat.

Creswell, Jhon W. 2010. Research Design, Pendekatan Kualitatif Kualitantif Dan Mixed. Edisi Ketiga Cetakan Pertama. Yogyakarata: Pustaka Pelajar.

Coulter. .2007. Manajemen. Jakarta: Indeks.

Donni Juni Priansa, Suwanto. 2011. Manajemen Sumber Daya Manusia Dalam Organisasi Publik dan Bisnis. Bandung : Alfabeta.

Gary, Dessler. 2010. Manajemen Sumber daya Manusia. Edisi kesepuluh Jilid $1 \&$ 2. Jakarta: PT Indeks Barat.

Gitosudarmo \& Sudita. 2008. Perilaku Keorganisasian. Jakarta: PT Persada.

Handoko, Hani. 2011. Manajemen Personalia \& Sumberdaya manusia. Yogyakarta: BPFE.

Hasibuan, Malayu. 2008. Manajemen Sumber Daya Manusia. Edisi Revisi. Cetak Kelima. Jakarta: Bumi Aksara.

Herdiansyah, Haris. 2010. Metodologi Penelitian Kualitatif untuk Ilmu- 
PUBLIK: Jurnal Manajemen Sumber Daya Manusia, Administrasi dan Pelayanan Publik

Sekolah Tinggi Ilmu Administrasi Bina Taruna Gorontalo Volume V Nomor 2 Desember 2018

Ilmu Sosial. Jakarta: Salemba Humanika.

Marwansyah. 2010. Manajemen Sumber Daya Manusia, Edisi Kedua. Bandung: Alfabeta.

Mathis, Robert L. \& John H. Jackson. 2006. Human Reseource Management:Manajemen Sumber Daya Manusia Edisi ke-10. Edisi Bahasa Indonesia. Jakarta: Salemba Empat.

Matondang. 2008. Kepemimpinan Budaya Organisasidan Manajemen Strategik.

Yogyakarta: Graha ilmu.

Moleong, Lexy J. 2010. Metodologi

Penelitian Kualitatif. Cetakan kedua. Bandung: PT Remaja Rosdakarya.

Nawai, Hadari. 2006. Kepemimpinan Yang Efektif. Yogyakarta, UGM Pers.

Rivai dan Mulyadi. 2012. Kepemimpinan dan Perilaku Organisasi. Jakarta: PT. Raja Grafindo Persada.

Robbins, Coulter. 2006. Organizational Behaviour. 12nd edition. New Jersey: Upper Saddle River.

Said, M. Mas'ud. 2010. Kepemimpinan: Pengembangan Organisasi Team Building dan Perilaku Inovatif. Malang: UIN-Maliki Press.

Saryono. 2010. Metodologi Penelitian Kualitatif dalam Bidang Kesehatan. Yogyakarta: Nuha Medika.

Serdamayanti. 2007. Perilaku Peranan. Jakarta: PT. Gramedia Pustaka.
Siagian, Sondang. P. 2008. Manajemen Sumber Daya Manusia. Jakarta: Penerbit Bumi Aksara.

Siswanto. 2009. Pengantar Manajemen. Jakarta Bumi Aksara. Dalam Dunia Pendidikan yang Kompetitif. Jakarta: Salemba Empat.

Soekanto, Soerjono. 2008. Teori Peran. Jakarta: Bumi Aksara.

Sofiandi, Herman. 2008. Manajemen Sumber Daya Manusia. Jakarta: Penerbit Graha.

Stoner, James A.F. 2006. Manajemen. Terjamahan Antarikso, dkk. Jakarta: Erlangga.

Sugiyono. 2010. Metode Penelitian Pendidikan Pendekatan Kuantitaf, Kualitatif, dan $R \& D$. Bandung: Alfabeta.

Susan, Novri. 2010. Pengantar Sosiologi Konflik dan Isu-isu Konflik Kontemporer. Jakarta: Kencana.

Suwanto \& Donni Juni Priansa. 2011. Manajemen Sumber Daya Manusia Dalam Organisasi Dan Bisnis. Bandung: Alfabeta.

Syaifudin. 2008. Penyusunan Skala Psikologi. Yogyakarta: Pustaka Pelajar.

Terry, R. George. 2013. Prinsip-prinsip Manajemen. Jakarta PT Bumi Aksara.
............... 2010. Dasar-Dasar Manajemen. Jakarta: Bumi Aksara.

Thoha, Miftah. 2009. Kepemimpinan Dalam Manajemen. Jakarta: PT Raja Grafindo Persada. 
PUBLIK: Jurnal Manajemen Sumber Daya Manusia, Administrasi dan Pelayanan Publik Sekolah Tinggi Ilmu Administrasi Bina Taruna Gorontalo Volume V Nomor 2 Desember 2018

Urwick, 2008. "the manager's span of control," Harvard Business Review.

Widjaja, A.W. 2008. Otonomi Desa Merupakan Otonomi Bulat, dan Utuh. Jakarta: PT Raja Grafindo Persada. 